\title{
A Box-Behnken design for predicting the combined effects of relative humidity and temperature on antagonistic yeast population density at the surface of apples
}

\author{
Rachid Lahlali $^{\text {a,* }}{ }^{\text {, Sébastien Massart }}{ }^{\text {a }}$, M. Najib Serrhini ${ }^{\text {b }}$, M. Haïssam Jijakli ${ }^{\text {a }}$ \\ ${ }^{a}$ Unité de Phytopathologie, Faculté Universitaire des Sciences Agronomiques de Gembloux, Passage des Déportés 2, 5030 Gembloux, Belgium \\ ${ }^{\mathrm{b}}$ Département de Phytopathologie, Ecole Nationale d'Agriculture de Meknès, B P S/40, 50001 Meknès, Morocco
}

Received 10 April 2007; received in revised form 5 September 2007; accepted 19 November 2007

\begin{abstract}
The objective of this work was to develop models predicting the combined effects of relative humidity (RH, $75-98 \%)$, temperature $\left(5-25^{\circ} \mathrm{C}\right)$, and initial applied yeast concentration $\left(10^{4}-10^{8} \mathrm{CFU} / \mathrm{ml}\right)$ on the apple-surface population densities of two biocontrol agents fused against postharvest diseases; the antagonistic yeasts Pichia anomala strain K and Candida oleophila strain O. Experiments were carried out according to a Box-Behnken matrix. Multiple regression analyses showed that both models yielded a good prediction of yeast density. The effect of relative humidity appeared greater than that of temperature. The number of yeast colony-forming units per square centimeter of apple fruit surface increased with increasing relative humidity, temperature, and initial applied yeast concentration. The models predict that under optimal growth conditions $\left(25^{\circ} \mathrm{C}, 98 \%\right)$, strains $\mathrm{O}$ and $\mathrm{K}$ should reach a density of $10^{4} \mathrm{CFU} / \mathrm{cm}^{2}$ when applied initially at $2 \times 10^{7}$ (strain $\mathrm{O}$ ) or $10^{7} \mathrm{CFU} / \mathrm{ml}(\mathrm{strain}$ $\mathrm{K})$. The model results suggest that rainfall was likely the principal cause of the variability of yeast efficacy reported for previous preharvest orchard trials spanning two successive years. Temperature may also contribute to this variation. The models developed here are important tools for predicting population densities of both strains on the apple surface within the experimental limits. The use of these results should contribute to achieving yeast densities of $10^{4} \mathrm{CFU} / \mathrm{cm}^{2}$ on apples by controlling yeast application and environmental factors such as relative humidity and temperature. The results of this study also confirm our previous in vitro findings that water activity has a greater effect than temperature on yeast population density.
\end{abstract}

(C) 2007 Elsevier B.V. All rights reserved.

Keywords: Population density; Pichia anomala strain K; Candida oleophila strain O; Relative humidity; Temperature and Box-Behnken design

\section{Introduction}

Biological control of postharvest diseases of fruits appears as a realistic alternative to fungicide application, as only the fruits need to be treated, environmental factors are defined and stabilized in storage rooms, so that harvested commodities will have high value (Fokkema, 1991; Wilson and Wisniewski, 1994; Jijakli et al., 1999). Biocontrol of postharvest fruit decays is achievable by postharvest application of antagonists and by preharvest spraying of biocontrol agents in the field (Benbow and Sugar 1999; Korsten et al., 1997; Leibinger et al., 1997; Teixidõ et al., 1998a). In the latter practice, the antagonist is

\footnotetext{
* Corresponding author. Tel.: +32 81622431; fax: +32 81610126 .

E-mail address: r.lahlali@hotmail.com (R. Lahlali).
}

applied just before harvest so that it can colonize the fruit surface and any wounds inflicted during harvest before the arrival of wound pathogens (Ippolito and Nigro, 2000). Yet authors highlight the very real practical problem of promoting the effective establishment of prospective antagonists in a natural environment. This can be crucial, limiting the consistency of biocontrol under field conditions and the widespread commercialization of biocontrol agents.

The fluctuation of abiotic factors such as temperature, water availability, relative humidity and UV radiation has the greatest impact on the growth and biological proprieties of prospective biocontrol agents (Magan, 2001; Teixidõ et al., 1999). Tolerance to such abiotic fluctuations is a prerequisite to successful application of ecologically competent biocontrol agents under field conditions (Elad, 1990). Such tolerance will 
make it possible to establish a high biocontrol agent (BCA) population density. Physiological manipulation of antagonists has focused on improving their ecological fitness, which is particularly important in orchard applications where environmental conditions fluctuate widely (Janisiewicz and Korsten, 2002). Unfortunately, the study of the ecological fitness of antagonistic agents to be applied in the field has received little attention as compared with other topics such as mechanisms of action, genetic manipulation, and combination with chemical treatments. Nevertheless, some elegant studies on BCA desiccation tolerance have been published (Magan, 2001). Recent investigations carried out in vitro with the antagonistic yeast Candida sake (Teixidõ et al., 1998a) have shown that its in vitro growth is affected by environmental factors such as temperature, water activity, and $\mathrm{pH}$. The water activity of the culture medium used to produce the biocontrol agent inoculum before preharvest application to apple fruits has been found to influence preharvest population density but not the agent's efficacy against blue mold. (Teixidõ et al., 1998b,c).

To our knowledge, the effects of relative humidity and temperature on yeast population density at the fruit surface before storage has never been studied, although these factors are crucial to cell population development. McGuire (2000) reports that BCA cells must be applied at a sufficient density to be immediately available to colonize the fruit surface and superficial wounds. Generally, the antagonist much reach a surface density of at least $10^{4} \mathrm{CFU} / \mathrm{cm}^{2}$ for effective biological control (Andrews, 1992), and this density must be maintained during the first 2 weeks of cold storage in order to control effectively the decay resulting from injuries during postharvest processing (McGuire, 1994).

Pichia anomala (strain K) and Candida oleophila (strain O), two antagonistic yeasts, have been isolated from apples and selected for their biocontrol activities against postharvest diseases of apples, pears, and citrus fruits (Jijakli et al., 1999, 2004; Lahlali et al., 2004; Lahlali et al., 2005a). Efficacy trials carried out with these antagonistic yeasts on apple fruits under field conditions have shown that strain $\mathrm{K}$ or strain $\mathrm{O}$ population density has to reach the threshold of $10^{4} \mathrm{CFU} / \mathrm{cm}^{2}$ apple-fruit surface just after harvest in order to effectively control postharvest diseases (De Clercq et al., 2003).

The objective of the present research was to study the combined effects of temperature, relative humidity, and initial applied yeast concentration on the population density of both strains after a 48-h incubation under various combinations of these factors. For this purpose, response surface modeling is a valuable tool (Myers and Montgomery, 2002), as it can be used to determine the experimental-factor settings giving maximum (or minimum) response values. This methodology can also be used to determine the environmental conditions required to reach a yeast population density of $10^{4} \mathrm{CFU} / \mathrm{cm}^{2}$ or more. To reduce the number of experiments, a BoxBehnken design was used. This design minimizes the number of factor combinations required to evaluate the effects of three factors on a response. The combined effects are represented by means of a quadratic polynomial model for each antagonistic strain.

\section{Materials and methods}

\subsection{Yeast strains}

$P$. anomala strain $\mathrm{K}$ and $C$. oleophila strain $\mathrm{O}$ were grown on potato dextrose agar (PDA, Merck, Darmstadt, Germany) at $25{ }^{\circ} \mathrm{C}$ for three successive subcultures under the same conditions with an interval of $24 \mathrm{~h}$. Before application to the apples, yeast colonies were flooded with sterile distilled water and scraped from plates. The concentration of the strain $\mathrm{O}$ or strain $\mathrm{K}$ suspension was adjusted according to optical density measurements with an UltrospecII spectrophotometer (LKB Biochron Ltd., Uppsala, Sweden) at $595 \mathrm{~nm}$ (Jijakli and Lepoivre, 1998).

\subsection{Controlling chamber humidity}

Small growth chambers (desiccators) with a maximal capacity of 11 of water were used in these experiments. The approximate value of equilibrium relative humidity $(98 \pm 1$, $86.5 \pm 1$ and $75 \pm 1 \%$ ) inside the desiccators was controlled by means of saturated salt solutions: $\mathrm{K}_{2} \mathrm{SO}_{4}(98 \%)$, KCL (86.5\%), and $\mathrm{NaCl}(75 \%)$ (Xu et al., 2001). These pure salts were mixed in 11 of distilled water and stirred until a saturated salt solution was obtained. The resulting relative humidity varied slightly and gradually with temperature (Winstoon and Bates, 1960). Desiccators with different humidities were incubated for $48 \mathrm{~h}$ at the experimental temperature before introduction of the apples treated with the yeast $P$. anomala (strain $\mathrm{K}$ ) or $C$. oleophila (strain O). The relative humidity in each desiccator was monitored by means a thermohygrometer.

\subsection{Application of antagonistic yeasts to apple fruits}

'Golden delicious' apples were disinfected by soaking for $2 \mathrm{~min}$ in sodium hypochlorite solution $(10 \%)$, then rinsed twice in sterile distilled water. After drying for $1 \mathrm{~h}$, the fruits were treated with various concentrations of $C$. oleophila (strain O) or P. anomala (strain K) $\left(10^{4}, 5 \times 10^{7}\right.$ and $\left.10^{8} \mathrm{CFU} / \mathrm{ml}\right)$ by dipping in $400 \mathrm{ml}$ suspension for $2 \mathrm{~min}$.

\subsection{Incubation conditions and recovery of yeast cells}

The treated fruits were placed in desiccators at relative humidities (four apples per desiccator) and then incubated at various temperatures $\left(5,15\right.$ and $\left.25^{\circ} \mathrm{C}\right)$.

After $48 \mathrm{~h}$ of incubation, yeast cell recovery from intact fruit surfaces was performed as previously described (Massart et al., 2005). Briefly, apple fruits were introduced into 3000-ml plastic bags. Each bag contained 4 apples and $1000 \mathrm{ml} \mathrm{KBPT}$ washing buffer $\left[6.8 \mathrm{~g} \mathrm{KH}_{2} \mathrm{PO}_{4}(0.05 \mathrm{M}), 8.7 \mathrm{~g} \mathrm{~K}_{2} \mathrm{HPO}_{4}(0.05 \mathrm{M})\right.$, and $500 \mu \mathrm{l}$ Tween 80] (one plastic bag per treatment). The plastic bags were centrifuged for $20 \mathrm{~min}$ at 120 rounds per minute. After shaking, the KBPT buffer wash was serially diluted and plated in triplicate on semi-selective HST-PDA medium. Colony-forming units (CFUs) were counted out after a 72-h incubation at $25{ }^{\circ} \mathrm{C}$. The mean surface area of the apples was 
evaluated as previously described (De Clercq et al., 2003; Massart et al., 2005) according to the following linear regression curve: [Surface $\left(\right.$ in $\left.\mathrm{cm}^{2}\right)=0.488 \times$ volume displaced water $(\mathrm{ml})+66.1(r=0.99)]$. Three trials were carried out over time and each treatment contained 3 replicates per trial.

\subsection{Experimental design}

To determine the effect of temperature, relative humidity, and initial concentration on the number of CFUs per square centimeter of apple surface, response surface methodology was applied with a Box and Behnken (1960) experimental design (Table 1). This design led to studying the effects of three factors in a single block of 15 sets of test conditions and 3 central points. The order of the experiments was fully randomized. Three levels were attributed to each factor, coded as $-1,0,+1$ (Table 1). Statistical analysis was performed with the software package 'DESIGN-EXPERT ${ }^{\circledR}$ version 6.0.' (StatEase, Inc., Minneapolis, USA). A quadratic polynomial model was defined to fit the response:

$$
\begin{aligned}
Y & =\beta_{0}+\beta_{1} X_{\mathrm{T}}+\beta_{2} X_{\mathrm{RH}}+\beta_{3} X_{\mathrm{CON}}+\beta_{11}\left(X_{\mathrm{T}}\right)^{2}+\beta_{22}\left(X_{\mathrm{RH}}\right)^{2} \\
& +\beta_{33}\left(X_{\mathrm{CON}}\right)^{2}+\beta_{12} X_{\mathrm{T}} X_{\mathrm{RH}}+\beta_{13} X_{\mathrm{T}} X_{\mathrm{CON}}+\beta_{23} X_{\mathrm{RH}} X_{\mathrm{CON}}
\end{aligned}
$$

where $Y$ is the response expressed as $\log _{10}\left(\mathrm{CFU} / \mathrm{cm}^{2}\right.$ fruit surface) and $\beta_{0}$ is a constant coefficient of the model. The regression coefficients $\left(\beta_{1}, \beta_{2}\right.$ and $\left.\beta_{3}\right),\left(\beta_{11}, \beta_{22}\right.$ and $\left.\beta_{33}\right)$ and $\left(\beta_{12}, \beta_{13}\right.$ and $\left.\beta_{23}\right)$ respectively represent linear, quadratic, and interaction effects of the model, estimated by multiple regression analysis. $\mathrm{X}_{\mathrm{T}}$ (temperature), $\mathrm{X}_{\mathrm{RH}}$ (relative humidity), and $\mathrm{X}_{\mathrm{CON}}$ (initial concentration of yeast application) are coded variables ranging from -1 to +1 . Interpretation of the data was based on the signs (positive or negative effect on the response) and statistical significance of coefficients $(P<0.05)$. Interactions between two factors could appear as an antagonis- tic effect (negative coefficient) or a synergistic effect (positive coefficient).

Internal validation of prediction accuracy of the BoxBehnken models was based on statistical evaluation of the following tests: Root-Mean-Square Error (RMSE), bias index and accuracy factor, and the lack-of-fit test (Ross 1996; Samapundo et al., 2005; Lahlali et al., 2007). Practical evaluation of the two models was based on a comparison of the responses observed in orchard trials spanning 2 years with the responses predicted on the basis of the models and the measured variables.

RMSE $=\sqrt{\frac{\mathrm{RSS}}{n}}=\sqrt{\frac{\sum\left(\mu_{\text {observed }}-\mu_{\text {predicted }}\right)^{2}}{n}}$

Bias factor $=10\left[\sum \log \left(\mu_{\text {observed }} / \mu_{\text {predicted }}\right) / n\right]$

Accuracy factor $=10\left[\sum \log \left(\mu_{\text {observed }} / \mu_{\text {predicted }}\right) \mid / n\right]$

\section{Results}

3.1. Observed effects of temperature, relative humidity, and initial applied concentration on yeast density at the apple surface

The experimental values obtained for the yeast population density at the apple surface under the various conditions tested are shown in Table 1, columns 5 (strain O) and 7 (strain K). With neither of the strains was it possible to achieve the dersirable threshold density of $10^{4} \mathrm{CFU} / \mathrm{cm}^{2}$ when both the temperature and the relative humidity were low $\left(5\right.$ or $15{ }^{\circ} \mathrm{C}$; relative humidity $75 \%$ ). At higher temperature and/or relative humidity, this threshold was sometimes reached (see E2, E3,

Table 1

Experimental and predicted values of population densities, expressed in $\log _{10}\left(\mathrm{CFU} / \mathrm{cm}^{2}\right.$ apple fruit surface $)$

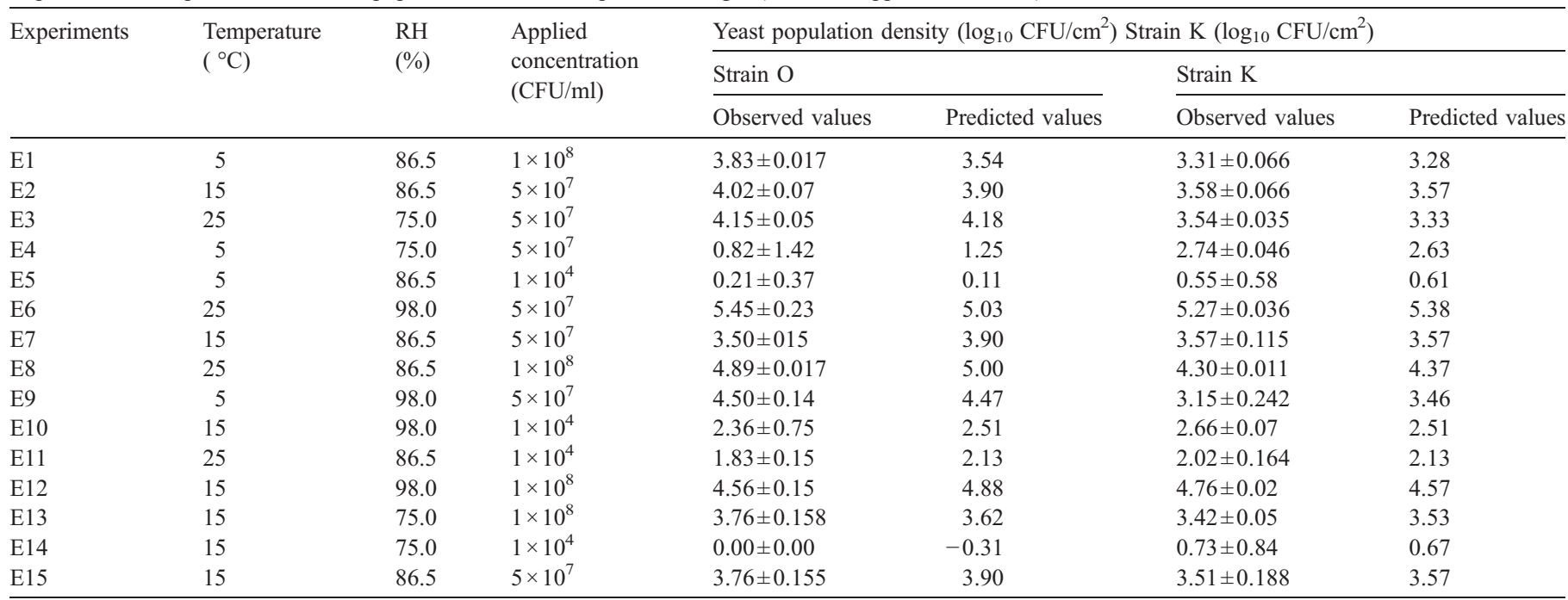

A Box-Behnken experimental design was applied with three controlled factors: temperature, relative humidity, and initial applied yeast concentration. 

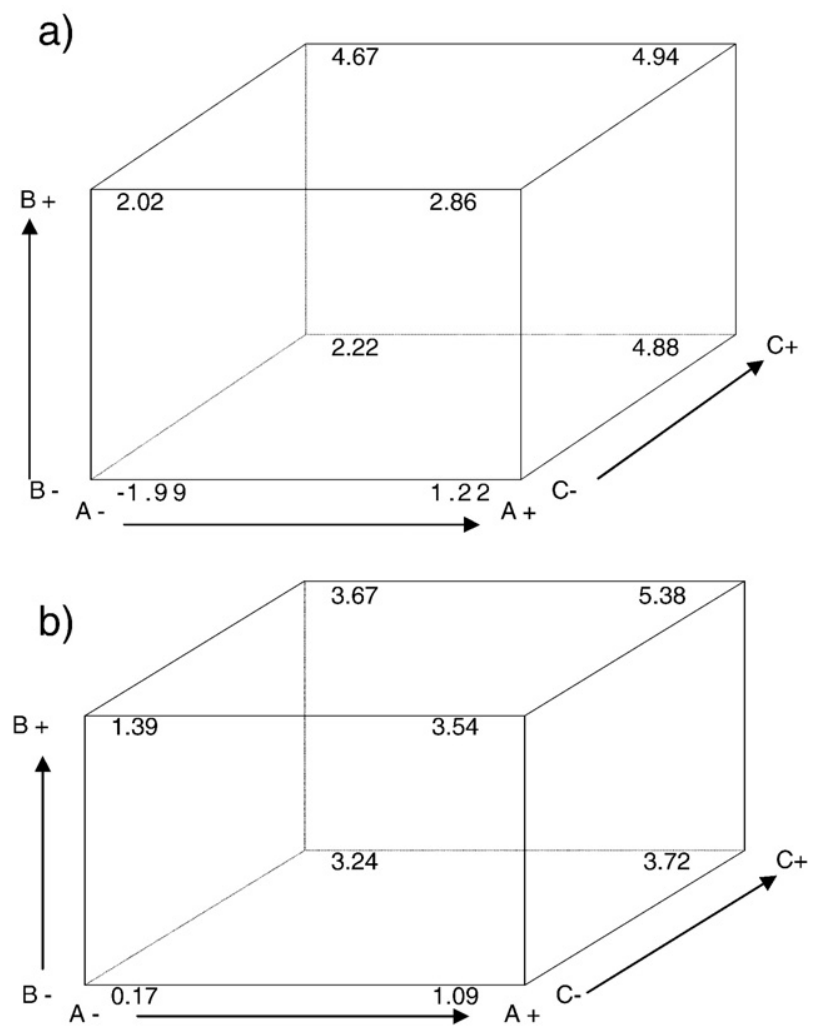

Fig. 1. Cubic presentation of the Box-Behnken (1960) experimental design for the yeast strains $C$. oleophilea strain $\mathrm{O}$ (a) and P. anomala strain $\mathrm{K}(\mathrm{b})$ : temperature $\left({ }^{\circ} \mathrm{C}\right)$; B: relative humidity $(\%)$; C: initial applied yeast concentration $(\mathrm{CFU} / \mathrm{ml})$.

E6, E8, E9, E12 for strain O; E6, E8, E12 for strain K). For each strain the highest density observed corresponded to $98 \%$ relative humidity, $25{ }^{\circ} \mathrm{C}$, and an initial applied concentration of $5 \times 10^{7} \mathrm{CFU} / \mathrm{ml}$.

\subsection{Modeling the effects}

Fig. 1 shows the maximal and minimal limits of the BoxBehnken experimental design adapted to evaluating the combined effects of initial concentration of yeast application, relative humidity, and temperature on the population density of C. oleophila strain $\mathrm{O}$ and $P$. anomala strain $\mathrm{K}$ (expressed in $\left.\log _{10}\left(\mathrm{CFU} / \mathrm{cm}^{2}\right)\right)$ at the apple surface. This population density could best be predicted by the following equations

(1)

$$
\begin{aligned}
Y_{1}= & 3.90+0.87 X_{\mathrm{T}}+1.02 X_{\mathrm{RH}}+1.58 X_{\mathrm{CON}} \\
& -0.072\left(X_{\mathrm{T}}\right)^{2}-0.092\left(X_{\mathrm{RH}}\right)^{2}-1.13\left(X_{\mathrm{CON}}\right)^{2} \\
& -0.02 X_{\mathrm{T}} \times X_{\mathrm{RH}}-0.23 X_{\mathrm{T}} \times X_{\mathrm{CON}}-0.30 X_{\mathrm{RH}} \\
& \times X_{\mathrm{CON}} .(\text { for } C . \text { oleophila } \text { strain } \mathrm{O})
\end{aligned}
$$

(2)

$$
\begin{aligned}
Y_{1}= & 3.57+0.65 X_{\mathrm{T}}+0.72 X_{\mathrm{RH}}+1.23 X_{\mathrm{CON}} \\
& -0.046\left(X_{\mathrm{T}}\right)^{2}+0.18\left(X_{\mathrm{RH}}\right)^{2}-0.92\left(X_{\mathrm{CON}}\right)^{2} \\
& -0.31 X_{\mathrm{T}} \times X_{\mathrm{RH}}-0.11 X_{\mathrm{T}} \times X_{\mathrm{CON}} \\
& -0.20 X_{\mathrm{RH}} \times X_{\mathrm{CON}} \cdot(\text { for } P . \text { anomala strain } \mathrm{K})
\end{aligned}
$$

where $Y_{1}$ and $Y_{2}$ are respectively the strain $\mathrm{O}$ and strain $\mathrm{K}$ densities on the apple surface $\left(\log _{10}\left(\mathrm{CFU} / \mathrm{cm}^{2}\right)\right)$ and $X$ is the coded value (between -1 and +1 ) of the factor indicated by the attached subscript ( $\mathrm{T}$ : temperature, $\mathrm{RH}$ : relative humidity, and CON: initial concentration).

The average predicted densities obtained with these yeast models under various conditions are summarized in Table 1, columns 6 and 8 . With both studied strains, differences were slight between the predicted and observed values. Both models predict a low yeast density on the fruit surface for the antagonist strain applied at a concentration of $10^{4} \mathrm{CFU} / \mathrm{ml}$ and incubated at a relative humidity ranging from 75 to $86.5 \%$ and an incubation temperature between 5 and $15{ }^{\circ} \mathrm{C}$. At $98 \%$ relative humidity, the initial applied concentration required to enable the yeast population to reach the threshold value of $10^{4} \mathrm{CFU} / \mathrm{cm}^{2}$ should be $2.810^{7} \mathrm{CFU} / \mathrm{ml}$ (strain $\mathrm{K}$ ) or $2.7 \times 10^{7} \mathrm{CFU} / \mathrm{ml}$ (strain O) at $15^{\circ} \mathrm{C}$ and $2 \times 10^{7} \mathrm{CFU} / \mathrm{ml}$ (strain O) or $10^{7} \mathrm{CFU} / \mathrm{ml}$ (strain $\mathrm{K}$ ) at $25^{\circ} \mathrm{C}$. At $98 \%$ relative humidity and $5{ }^{\circ} \mathrm{C}$, only strain $\mathrm{O}$ should be able to reach the threshold density (when applied at about $3.6 \times 10^{7} \mathrm{CFU} / \mathrm{ml}$ ).

For each model the $R^{2}$ (coefficient of determination) was calculated. This coefficient, ranging from 0 to 1 , represents the part of the response variation that is attributable to variations of the factors studied in the model and their interactions. The closer the $R^{2}$ value is to 1 the higher the predictive power of the model. In this case the values for $C$. oleophila strain $\mathrm{O}$ and $P$. anomala strain $\mathrm{K}$ were respectively 0.936 (93.6\%) and 0.958 $(95.8 \%)$ (Table 3$)$. This means that respectively only $6.4 \%$ and $4.2 \%$ of the total response variation remained unexplained by the model (Box and Draper, 1987). The fit is thus good between the quadratic model and the experimental data. The predicted and adjusted $R^{2}$ values were also calculated. The adjusted $R^{2}$ corrects the $R^{2}$ according to the sample size and the number of terms in the model. If there are many terms in the model and the sample size is not very large, the adjusted $R^{2}$ may be strikingly smaller than the $R^{2}$, and this should be a warning that the model may contain too many terms (Haaland, 1989). For strains O and K respectively, the predicted $R^{2}$ values were 0.88 and 0.92 and the adjusted $R^{2}$ vales were 0.92 and 0.94 (Table 3 ). These values are very similar and very close to the corresponding $R^{2}$ values. There is thus good agreement between the experimental and predicted values of the yeast population density on the apple fruit surface.

The purpose of statistical analysis is to determine which experimental factors generate signals that are large in comparison to the 'noise' (Haaland, 1989). 'Adequate precision' measures the signal-to-noise ratio. A ratio superior to 4 is generally desirable. For the strain $\mathrm{K}$ and strain $\mathrm{O}$ models the adequate precision was respectively 34.04 and 23.18 . This indicates an adequate signal (Table 3 ). The results of the multiple regression analysis from which the model coefficients were derived are listed in Table 2. The higher the absolute value of a linear coefficient $\left(\beta_{1}, \beta_{2}\right.$ or $\left.\beta_{3}\right)$, the greater the influence of the corresponding factor (Box and Draper, 1987) on the predicted density. With both strains, the applied initial yeast concentration had the greatest effect, followed by the relative humidity and finally by the temperature. In both models, all coefficients appeared significant, except for coefficients $\beta_{11}$ (quadratic effect of temperature), $\beta_{22}$ (quadratic effect of relative humidity), and 
Table 2

Significance of the coefficients used in the Box and Behnken (1960) experimental design adopted for estimating population densities of strain $\mathrm{O}$ or strain $\mathrm{K}$ on the apple surface, obtained after multiple regression analysis (T: temperature; RH: relative humidity and Con: initial applied concentration)

\begin{tabular}{lccr}
\hline & \multicolumn{2}{c}{ Antagonistic yeast } \\
\cline { 2 - 4 } & & Strain $\mathrm{O}$ & Strain $\mathrm{K}$ \\
\hline Response mean & $\beta_{0}$ & $3.90^{* *}$ & $3.57^{* *}$ \\
$T$ & $\beta_{1}$ & $0.87^{*}$ & $0.65^{* *}$ \\
$\mathrm{RH}$ & $\beta_{2}$ & $1.02^{* *}$ & $0.72^{* *}$ \\
$\mathrm{CON}$ & $\beta_{3}$ & $1.58^{* *}$ & $1.23^{* *}$ \\
$T^{2}$ & $\beta_{11}$ & $-0.072^{\mathrm{ns}}$ & $-0.046^{\mathrm{ns}}$ \\
$\mathrm{RH}^{2}$ & $\beta_{22}$ & $-0.092^{\mathrm{ns}}$ & $0.18^{\mathrm{ns}}$ \\
$\mathrm{CON}{ }^{2}$ & $\beta_{33}$ & $-1.13^{* *}$ & $-0.92^{* *}$ \\
$T \times \mathrm{RH}$ & $\beta_{12}$ & $-0.02^{* *}$ & $0.31^{* *}$ \\
$T \times \mathrm{CON}$ & $\beta_{13}$ & $-0.23^{\mathrm{ns}}$ & $-0.11^{\mathrm{ns}}$ \\
$\mathrm{RH} \times \mathrm{Con}$ & $\beta_{23}$ & $-0.30^{* *}$ & $-0.20^{*}$ \\
\hline$* \mathrm{Significant}$ & & &
\end{tabular}

* Significant.

** Highly significant.

$\beta_{13}$ (effect of the interaction between temperature and initial applied yeast concentration). In the strain $\mathrm{O}$ model, all coefficients except the linear ones have negative effects. In the strain $\mathrm{K}$ model, all coefficients have positive effects except the quadratic effects of temperature and relative humidity and the interactions (temperature $\times$ relative humidity) and (relative humidity $\times$ initial concentration of application).

\subsection{Statistical validation of the models}

The tests used to validate our predictive models are listed in Table 3. The values of the RMSE parameter show that both models produced predictions close to the observed data. The results of the $F$ test indicate that the predicted and observed values for both models are not significantly different.

For both strains, the bias index was close to 1.00 . This result implies that, for this experiment, both models are good predictors of yeast density on the apple surface. The accuracy factors show that the prediction differs from the observation by $11 \%$ for strain $\mathrm{O}$ and $12 \%$ for strain $\mathrm{K}$. The lack of fit is insignificant for both established models, suggesting that both quadratic models adequately approximate the true surfaces.

To determine the optimal conditions for high-density colonization of the apple surface by these strains, response surfaces showing the predicted effects of applied initial yeast concentration and relative humidity were drawn for three incubation temperatures from the equations for strain $\mathrm{O}$ (Fig. 2) and strain $\mathrm{K}$ (Fig. 3). The response surfaces show that the population density of both strains is strongly influenced by all three studied factors. At constant relative humidity and temperature, a higher initial yeast concentration leads to a higher final surface density. The highest yeast population densities are seen at the highest relative humidity values. Very low population densities are calculated for the lowest relative humidity level, especially at lower temperatures. As suggested by the experimental results, the conditions predicted to be optimal for both strains were $25^{\circ} \mathrm{C}, 98 \%$ relative humidity, and an initial applied concentration of about $5 \times 10^{7} \mathrm{CFU} / \mathrm{ml}$.

\subsection{Practical validation of the models}

In preharvest orchard trials carried out previously (De Clercq et al., 2003), contradictory results were obtained with strain O or strain $\mathrm{K}$ applied initially at $10^{7} \mathrm{CFU} / \mathrm{ml}$. In the first trial year, the yeast population density on the apple surface reached approximately $10^{4} \mathrm{CFU} / \mathrm{cm}^{2}$ and a high level of protection against $B$. cinerea and $P$. expansum was observed. The second trial year, the density achieved was much lower. The average temperature was $25^{\circ} \mathrm{C}$ the first year and $19^{\circ} \mathrm{C}$ the second year. The relative humidity was almost stable, ranging between 98 and $100 \%$ during both campaigns.

These data were incorporated into the models described above, and the results are shown in Table 4. For the first year, the strain K model predicted fairly accurately the strain K density on the apple surface (predicted value: $1.13 \times 10^{4} \mathrm{CFU} / \mathrm{cm}^{2}$; measured value: $\left.1.6 \times 10^{4}\right)$. The strain $\mathrm{O}$ model underestimated the strain $\mathrm{O}$ density by a factor of 10 (predicted value: $2.9 \times 10^{3} \mathrm{CFU} / \mathrm{cm}^{2}$; measured value: $3 \times 10^{4}$ ). For the second trial year, both models predicted somewhat lower densities than for the first year, but the actual measured values $\left(<10 \mathrm{CFU} / \mathrm{cm}^{2}\right)$ were much lower than the predicted ones $\left(\geq 1.9 \times 10^{3} \mathrm{CFU} / \mathrm{cm}^{2}\right)$. This means that temperature and relative humidity cannot fully explain the observed variation. It is necessary to take into account an additional, unknown cause. The preharvest treatments were performed 2 days before harvest in year 1 and 3 days before harvest in year 2 . Strong rains in year 2 may have been a major factor explaining the discrepancy.

\section{Discussion}

It should be possible to suppress postharvest diseases of fruits by field and/or postharvest application of a biocontrol agent. The combination of field and postharvest application has great potential for achieving effective control of postharvest decays (Janisiewicz and Korsten, 2002).

Most reports on biocontrol agents have focused on postharvest application (Spadaro and Gullino, 2004), but field application seems a promising way to achieve effective protection against some postharvest diseases (Benbow and Sugar, 1999), provided the BCA population density reaches a sufficient level to allow good colonization of inflicted wounds. Unpredictable climate changes can interfere with population growth, however, and thus affect the efficacy against postharvest

\section{Table 3}

ANOVA of quadratic response surface models for $C$. oleophila strain $\mathrm{O}$ and $P$. anomala strain $\mathrm{K}$

\begin{tabular}{lcc}
\hline & Strain $\mathrm{O}$ & Strain $\mathrm{K}$ \\
\hline$R^{2}$ & 0.936 & 0.958 \\
RMSE & 0.49 & 0.30 \\
Adjusted $R^{2}$ & 0.92 & 0.947 \\
Predicted $R^{2}$ & 0.88 & 0.926 \\
Adequacy precision & 23.18 & 34.047 \\
$F$-value model & 57.33 & 88.93 \\
Lack of fit $F$-value & 2.39 & 2.87 \\
Bias indice & 1.006 & 0.9942 \\
Accuracy indice & 1.117 & 1.121 \\
\hline
\end{tabular}



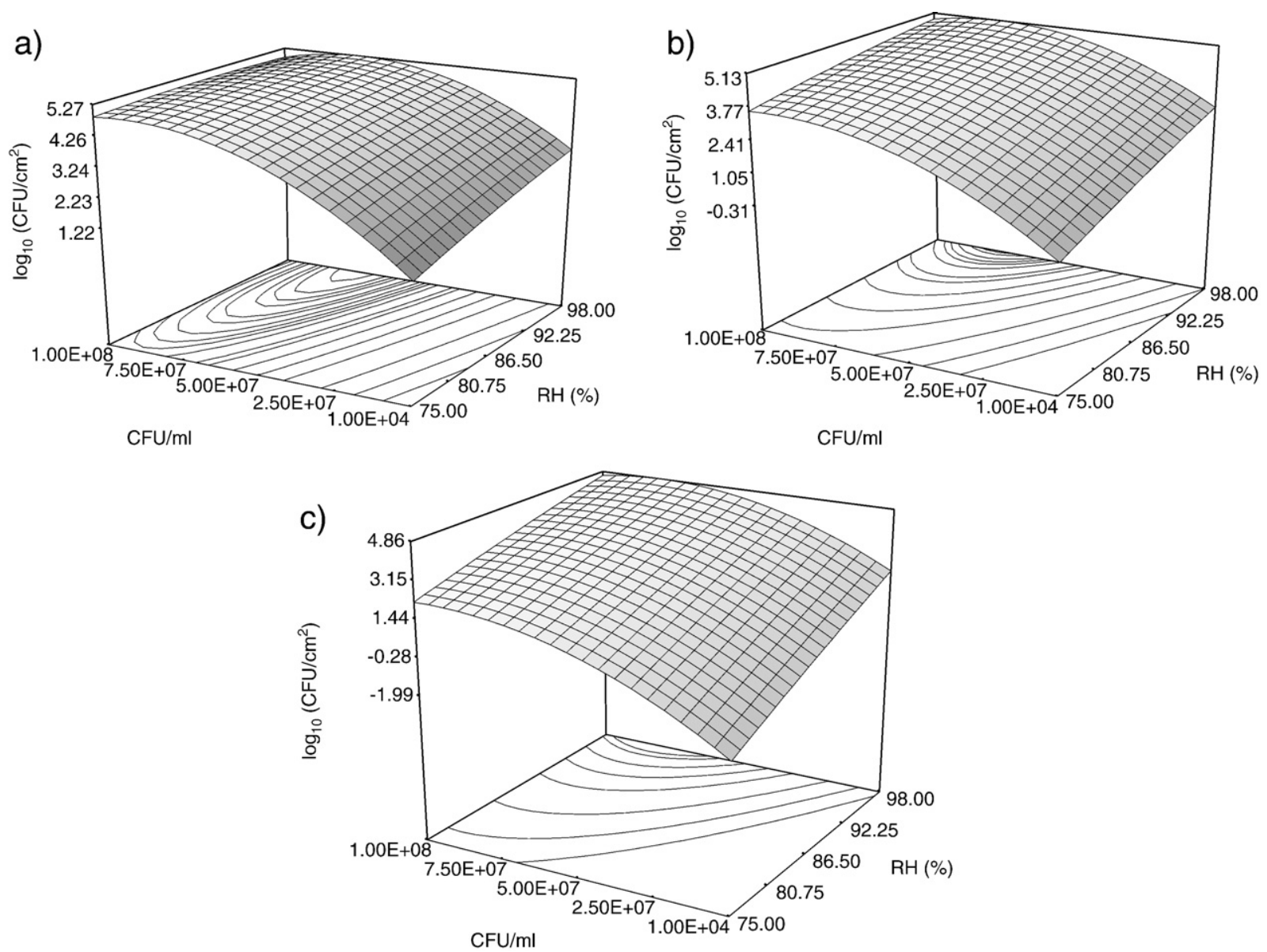

Fig. 2. Response surface curves showing the predicted effects of relative humidity and initial applied yeast concentration on the density of $C$. oleophila strain $\mathrm{O}$ at 25 (a), 15 (b) and $5{ }^{\circ} \mathrm{C}(\mathrm{c})$.

decay. Ippolito and Nigro (2000) stress that the efficacy of preharvest treatments depends on factors such as rain, wind, temperature, and relative humidity. There is thus an urgent need to evaluate and model the influence of environmental factors on BCA population density. With adequate models it should be possible to predict the BCA density on the apple surface before storage.

The main objectives of this study were to evaluate and model the influence of temperature, relative humidity, and applied initial yeast concentration on the population density of $P$. anomala strain $\mathrm{K}$ and C. oleophila strain $\mathrm{O}$ on the apple surface under controlled conditions. To our knowledge, this is the first attempt to model the influence of such factors on the establishment of biocontrol agents on the apple surface.

The modeling approach used was response surface methodology applied to the Box and Behnken (1960) experimental design. This design allows prediction of the combined effects of three controlled factors. In our experiment we examined the effects of temperature, relative humidity, and initial applied yeast concentration on the yeast density at the apple surface $48 \mathrm{~h}$ after treatment. The Box-Behnken design minimizes the number of factor combinations and maintains good precision of the predicted response. It has been widely used to predict the growth of food-borne pathogens in relation to at least three environment factors (Sautour et al., 2003).
In our models, the factors showing the greatest influence on yeast density at the apple surface are the initial yeast concentration and the relative humidity. Of the two environmental factors tested, relative humidity has a greater effect than temperature. This result is in agreement with the results of Artes et al. (1995) who, focusing on 'Satsuma' mandarins, found the density of an antagonistic yeast on the fruit surface to increase with relative humidity.

In our experiments and model predictions, the yeast population density was found to increase with increasing relative humidity and increasing incubation temperature. These results are in accordance with in vitro data showing a positive correlation between yeast growth and both the water activity of the medium and the incubation temperature (Lahlali, 2006). Our results are also in agreement with in vitro data showing that strain $\mathrm{O}$ reaches a higher concentration than strain $\mathrm{K}$ at $5{ }^{\circ} \mathrm{C}$, whatever the water activity (Lahlali, 2006).

Previous studies in our laboratory have shown that a yeast density of at least $10^{4} \mathrm{CFU} / \mathrm{cm}^{2}$ must be reached with both strains in order to achieve good protection against $P$. expansum and B. cinerea (De Clercq et al., 2003). In previous orchard trials carried out over two successive years, we actually measured such densities and observed effective protection during two successive years of trials. It was therefore interesting to incorporate the meteorological data related to both years into 
a)

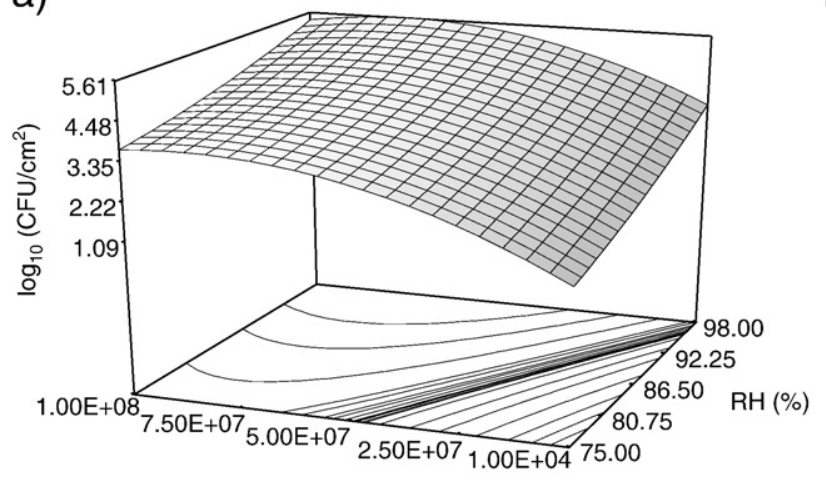

b)

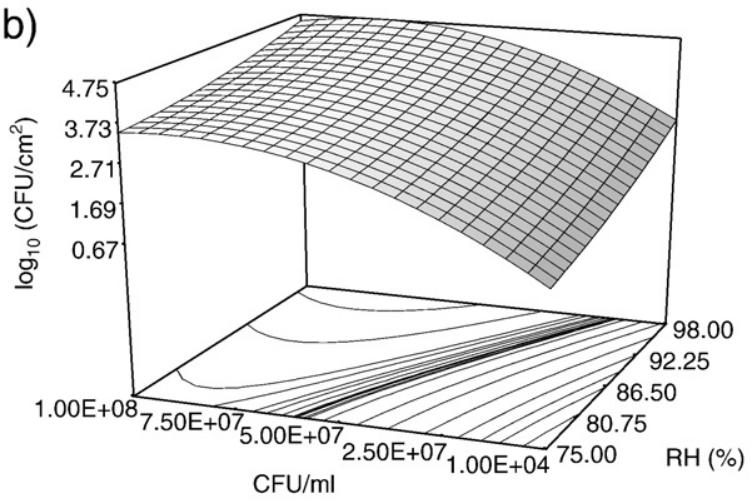

$\mathrm{CFU} / \mathrm{ml}$

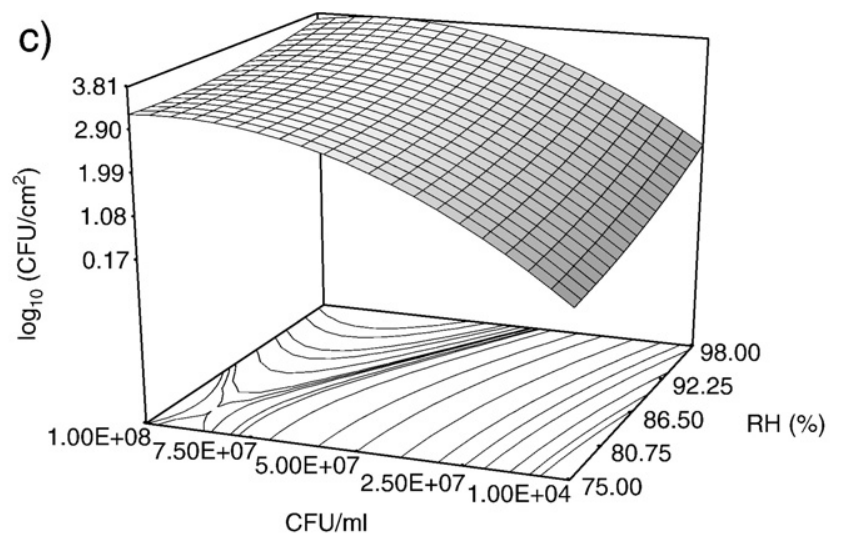

Fig. 3. Response surface curves showing the predicted effects of relative humidity and initial applied yeast concentration on the density of $P$. anomala strain $\mathrm{K}$ at 25 (a), 15 (b) and $5^{\circ} \mathrm{C}(\mathrm{c})$.

our models, to see if these would predict big differences between the 2 years. It turns out that our models describe reasonably well what happened the first year (especially as regards strain K), but not the second. We suspect that preharvest rainfall may be the major factor contributing to the poor performance of our models for the second year (De Clercq et al., 2003). Teixidõ et al. (1999) reported that $C$. sake populations reached $48 \mathrm{~h}$ after biological treatment were much higher in the first season of their trial $\left(25^{\circ} \mathrm{C}\right)$ than in the second $\left(32{ }^{\circ} \mathrm{C}\right)$.

Another aim of this work was to determine temperature, relative humidity, and initial concentration conditions making it possible to reach the threshold population density of $10^{4} \mathrm{CFU} /$ $\mathrm{cm}^{2}$. Our models predict that this threshold should be reached by both strains under favorable conditions: $25^{\circ} \mathrm{C}, 98 \%$ relative

Table 4

Comparison of predicted and measured values for years 1 and 2 of a published orchard trial ${ }^{1}$

\begin{tabular}{llllll}
\hline Year of trial & \multicolumn{2}{l}{$\begin{array}{l}\text { Predicted values } \\
\left(\mathrm{CFU} / \mathrm{cm}^{2}\right)\end{array}$} & & \multicolumn{2}{l}{$\begin{array}{l}\text { Measured values } \\
\left(\mathrm{CFU} / \mathrm{cm}^{2}\right)\end{array}$} \\
\cline { 2 - 3 } \cline { 5 - 6 } & Strain O & Strain $\mathrm{K}$ & & Strain O & Strain $\mathrm{K}$ \\
\hline Year 1 $^{\mathrm{a}}$ & $2.9 \times 10^{3}$ & $1.13 \times 10^{4 *}$ & & $3 \times 10^{4}$ & $1.6 \times 10^{4 *}$ \\
Year 2 $^{\mathrm{b}}$ & $1.9 \times 10^{3}$ & $2.89 \times 10^{3}$ & & $<10$ & $<10$ \\
\hline
\end{tabular}

${ }^{\text {a }}$ Preharvest trials performed 2 days before harvest (Low spray volume).

${ }^{b}$ Preharvest trials performed 3 days before harvest (Low spray volume).

*Predicted and practical values $\geq 10^{4} \mathrm{CFU} / \mathrm{cm}^{2}$.

${ }^{1}$ De Clercq et al., 2003. humidity, and an applied concentration of about $10^{7}$ for strain $\mathrm{K}$ and $2 \times 10^{7} \mathrm{CFU} / \mathrm{ml}$ for strain $\mathrm{O}$. These results are in agreement with those reported by Lahlali and Jijakli (2004), showing that under prevailing temperature conditions and at a relative humidity near $100 \%$, it should take at least $10^{7}$ to $10^{8} \mathrm{CFU} /$ $\mathrm{ml}$ strain $\mathrm{K}$ or strain $\mathrm{O}$ to reach this threshold density on the apple surface.

Mercier and Wilson (1995) have studied the effect of relative humidity on the growth of $C$. oleophila and $B$. cinerea on wounded apples. They report that the population density of both microorganisms increases fast when water is periodically applied to wounds on the fruit. These results raise the possibility that moisture, being a limiting factor for both the antagonist and the pathogen, might be involved in the mechanisms of biocontrol. So far, little is known about the antagonistic action of agents used in the biocontrol of postharvest diseases. Competition for moisture should be included as a possibility.

Our models show a positive correlation between the population density of antagonistic yeasts and both temperature and relative humidity, with a greater effect of the latter. Similar results have been obtained in vitro with the yeast C. sake, another biocontrol agent for postharvest diseases of apples. In this case, the effect of $a_{w}$ was much more pronounced than that of temperature or $\mathrm{pH}$ (Teixidõ et al., 1998a,b).

Models based on multi-factor analyses like those described here are valid only for the specific strain/substrate combination studied and within the experimental domain (Delignette-Muller, 
1997; Lahlali et al., 2005b, 2007). Any extrapolation to other strains or growth substrates or beyond the tested ranges of the considered factors would be hazardous. Consequently, it is important to specify any conditions under which a model proves inadequate (Barayni et al., 1996). In our case, we have no basis for comparison, as we know of no other published models describing the combined effects of relative humidity, temperature and initial applied yeast concentration on yeast density at the apple surface. As mentioned above, preharvest rainfall would appear to reduce the predictive power of our models (De Clercq et al., 2003).

In conclusion, the present results may help in choosing the concentration of yeast suspensions to be applied in order to achieve on the apple surface a yeast density of at least $10^{4} \mathrm{CFU} / \mathrm{cm}^{2}$, required for protection against pathogens affecting wounded apples in storage. Our models may also provide guidance as to how to control this density by altering two key environmental factors, temperature and the relative humidity. Both models are capable of predicting the yeast population densities on the apple surface $48 \mathrm{~h}$ after field spraying of biocontrol agents, and they might be useful in deciding whether preharvest treatment is sufficient to allow fast colonization of wounds inflicted during harvest and packaging, prior to the arrival of wound pathogens, or whether it is wise to apply further postharvest treatment to increase the yeast population density and thus ensure better protection against postharvest apple decays arising in the storage room.

\section{Acknowledgements}

This work was achieved by a postdoctoral fellowship granted by the Plant Pathology Unit and Gembloux Agricultural University for first author Rachid Lahlali.

\section{References}

Andrews, J.H., 1992. Biological control in the phyllosphere. Annual Review of Phytopathology 30, 603-635.

Artes, F., Rodriguez, M.C., Martinez, J.A., Marin, J.G., 1995. Influence of fungicide treatment and storage conditions on mould and yeast activity on 'Satsuma' mandarin. International Journal of Refrigeration 18, 64-66.

Baranyi, J., Ross, T., McMeekin, T.A., Roberts, T.A., 1996. Effects of parameterization on the performance of empirical models used in predictive microbiology. Food Microbiology 13, 83-91.

Benbow, J.M., Sugar, D., 1999. Fruit surface colonization and biological control of postharvest diseases of pear by pre-harvest yeast applications. Plant Disease 83, 839-844.

Box, G.E.P., Behnken, D.W., 1960. Some new three level design for study of quantitative variables. Technometerics 2, 455-476.

Box, G.E.P., Draper, N.R., 1987. Least squares for response surface work. Empirical Model Building and Response Surfaces. John Wiley, New York, pp. 34-103.

De Clercq, D., Cognet, S., Pujol, M., Lepoivre, P., Jijakli, M.H., 2003. Development of a SCAR marker and a semi-selective medium for specific quantification of Pichia anomala strain $\mathrm{K}$ on apple fruit surfaces. Postharvest Biology and Technology 29, 237-247.

Delignette-Muller, M.-L., 1997. La microbiologie prévisonnelle: approches méthodologiques. Bulletin de la société Française de Microbiologie 12, $31-36$.

Elad, Y., 1990. Reasons for delay in development of biological control of rose and foliar pathogens. Phytoparasitica 18, 99-105.
Fokkema, N.J., 1991. The phyllosophere as ecologically neglected milieu: a plant pathologist's point of view. In: Andrews, J.H., Hirano, S.S. (Eds.), Microbial Ecology of Leaves. prenger-Verlag, Madison, USA, pp. 3-18.

Haaland, P.D., 1989. Statistical problem solving. In: Deeker, M. (Ed.), Experimental design in biotechnology. New York and Basel, pp. 1-18.

Ippolito, A., Nigro, F., 2000. Impact of preharvest application of biological control agents on postharvest diseases of fresh fruits and vegetables. Crop Protection 19, 715-723.

Janisiewicz, W.J., Korsten, L., 2002. Biological control of post-harvest diseases of fruits. Annual Review of Phytopathology 40, 411-441.

Jijakli, M.H., Lepoivre, P., 1998. Characterization of an exo-b-1,3-glucanase produced by Pichia anomala strain K, antagonist of Botrytis cinerea on apples. Phytopathology 88, 335-343.

Jijakli, M.H., Lassois, L., Lahlali, R., 2004. Antagonistic activity of yeast against post-harvest diseases of tropical fruits. Bull. Séanc. Acad. R. Sci. Outre-Mer 50 (2), 153-163.

Jijakli, M.H., Lepoivre, P., Grevesse, C., 1999. Yeast species for biocontrol of apple postharvest diseases: an encouraging case of study for practical use. In: Upadhyay, R.K., Mukerij, K.G. (Eds.), Biotechnological Approaches in Biocontrol of Plant Pathogens. Kluwer. Academic/Plenum Publishers, NewYork, pp. 31-49.

Korsten, L., De Villiers, E.E., Wehner, F.C., Kotz'e, J.M., 1997. Field sprays of Bacillus subtilis and fungicides for control of preharvest fruit diseases of avocado in South Africa. Plant Disease 81, 455-459.

Lahlali, R., 2006. Study and modelling of the ecological behaviour of Botrytis cinerea Pers., Penicillium expansum Link. and both antagonistic yeasts Candida oleophila (strain O) and Pichia anomala (strain K) against these pathogens of apples in postharvest (Ph.D in French). FUSAGx, Belgium.

Lahlali, R., Jijakli, M.H., 2004. Evaluation of population density of Pichia anomala strain $\mathrm{K}$ and Candida oleophila strain $\mathrm{O}$ and their protection against Penicillium expansum link on apples. IOBC/WPRS Bulletin 27, 340-346.

Lahlali, R., Serrhini, M.N., Jijakli, M.H., 2004. Efficacy assessment of Candida oleophila (strain $\mathrm{O}$ ) and Pichia anomala (strain K) against major postharvest diseases of citrus fruits in Morocco. Commun. Agric. Appl. Biol. Sci. 64, 601-609 Ghent University.

Lahlali, R., Serrhini, M.N., Jijakli, M.H., 2005a. Development of a biological control methods against postharvest diseases of citrus fruits. Commun. Agric. Appl. Biol. Sci. 70/3, 47-58 Ghent University.

Lahlali, R., Serrhini, M.N., Jijakli, M.H., 2005b. Studying and modelling the combined effect of water activity and temperature on growth rate of $P$. expansum. International Journal of Food Microbiology 103, 315-322.

Lahlali, R., Serrhini, M.N., Friel, D., Jijakli, M.H., 2007. Predictive modelling of temperature and water activity (solutes) on the in vitro radial growth of Botrytis cinerea Pers. International Journal of Food Microbiology 114, 1-9.

Leibinger, W., Breuker, B., Hahn, M., Mendgen, K., 1997. Control of postharvest pathogens and colonization of the apple surface by antagonistic microorganisms in the field. Phytopathology 7, 1103-1110.

Magan, N., 2001. Physiological approaches to improving the ecological fitness of fungal biocontrol agents. Fungi as Biocontrol Agents. Progress, problems and Potential. CABI Publishing, Bristol. 390 pp.

Massart, S., De Clercq, D., Salmon, M., Dickburt, C., Jijakli, M.H., 2005. Development of real-time PCR using minor groove binding probe to monitor the biological control agent Candida oleophila (strain O). Journal of Microbiological Methods 60, 73-82.

McGuire, R.G., 1994. Application of Candida guilliermondii in commercial citrus coatings for biocontrol of Penicillium digitatum on grape fruits. Biological Control 4, 1-7.

McGuire, R.G., 2000. Population dynamics of potharvest decay antagonists growing epiphytically and within wounds on grapefruit. Phytopathology 90, $1217-1223$.

Mercier, J., Wilson, C.L., 1995. Effect of wound moisture on the biocontrol by Candida oleophila of gray mold rot (Botrytis cinerea) of apple. Postharvest Biology and Technology 6, 9-15.

Myers, R.H., Montgomery, D.C., 2002. Response surface Methodology: Process and product Optimization Using Designed Experiments. John Wiley \& Sons Inc., New York. 
Ross, T., 1996. Indices for performance evaluation of predictive models in food microbiology. Journal of Applied Bacteriology 81, 501-508.

Samapundo, S., Devlieghere, F., De Meulenar, B., Geeraerd, A.H., Van Impe, J. F., Debevere, J.M., 2005. Predictive modelling of the individual and combined effect of water activity and temperature on the radial growth of Fusarium verticilloides and $F$. Proliferatum on corn. International Journal of Food Microbiology 105, 35-52.

Sautour, M., Mary, P., Chihib, N.E., Hornez, J.P., 2003. The effects of temperature, water activity and $\mathrm{pH}$ on the growth of Aeromons hydrophila and on its subsequent survival in microcosm water. Journal of Applied Microbiology 95, 807-813.

Spadaro, D., Gullino, M.L., 2004. State of the art and future prospects of the biological control of postharvest fruity diseases. International Journal of Food Microbiology 91, 185-194.

Teixidõ, N., Vinãs, I., Usall, J., Sanchis, V., Magan, N., 1998a. Ecophysiological responses of the biocontrol yeast of Candida sake to water, temperature and pH stress. Journal of Applied Microbiology 84, 192-200.
Teixidõ, N., Vinãs, I., Usall, J., Magan, N., 1998b. Improving ecological fitness and environmental stress tolerance of the biocontrol yeast Candida sake by manipulation of intracellular sugar alcohol and sugar content. Mycological Research 102 (11), 1409-1417.

Teixidó, N., Viñas, I., Usall, J., Magan, N., 1998c. Control of blue mold of apples by preharvest application of Candida sake grown in media with different water activity. Phytopathololgy 88, 960-964.

Teixidõ, N., Usall, J., Viñas, I., 1999. Efficacy of preharvest and postharvest Candida sake biocontrol treatments to prevent blue mould on apples during cold storage. International Journal of Food Microbiology 50, 203-210.

Wilson, L., Wisniewski, M.E., 1994. Biological Control of Postharvest Diseases: Theory and Practice. CRC Press, London, UK. 182 pp.

Winston, P.W., Bates, D.H., 1960. Saturated solutions for the control humidity in biological research. Ecology 41, 232-237.

Xu, X.M., Guerin, L., Robinson, J.D., 2001. Effects of temperature and relative humidity on conidial germination and viability, colonization and sporulation of Monilia fructigena. Plant Pathology 50, 561-568. 